\title{
Examination of the Community Pharmacists' Intention to Pharmacist Partnership Using the Theory of Planned Behavior: A Structural Equation Model
}

\author{
Miray Arslan*, Nilay Tarhan, Sevgi Şar \\ Department of Pharmacy Management. Ankara University Faculty of Pharmacy, 06100. Anadolu-Ankara, TURKEY.
}

\begin{abstract}
Background: The ownership types of pharmacies are important because it plays a significant role at the services provided by pharmacists. The competitive structure of community pharmacy sector might prompt pharmacists to pay attention for business issues more than health issues. Similar to all businesses, community pharmacists must protect their profitability to continue their profession functions. In this context, partnerships are thought as a solution for taking market advantage in community pharmacy sector. Aims: The aim of this study is modeling the community pharmacists' intention towards pharmacist partnership by the Theory of Planned Behavior (TPB). Attitudes, subjective norms and perceived behavioral control are used as estimators of the partnership intention. Methods and Material: The measurement tool was applied face to face to a random sample of 392 community pharmacists within Ankara, Turkey. Two-sample independent t-test and ANOVA are used to determine significant differences between groups. The structural equation model (SEM) is used for modeling the pharmacists' partnership intention. Results: A response rate of $77 \%$ was achieved. Developed "Partnership Intention of Community Pharmacists (PICP)" model provided a good fit to the data and explain $66 \%$ of the variation in the community pharmacists' partnership intention. One unit increase in the "positive attitudes towards behavior" factor leads 0.22 units increase, one unit increase in the "negative attitudes towards behavior" factor leads 0.15 units decrease, one unit increase in the "subjective norms" factor leads 0.37 increase, and one unit increase in the "perceived behavioral control" factor leads 0.21 units in the "partnership intention". Conclusions: The present work contributes to the literature by developing a structural model for partnership intention that contains attitudes, subjective norms, and perceived behavioral control. The extension of the PICP model can be used in modeling the pharmacists' behaviors toward pharmacist partnership.
\end{abstract}

Key words: Community Pharmacist, Pharmacist Partnership, Theory of Planned Behavior, Structural Equation Model.

Key Messages: The originality of this study lies in being the first study that focused on attitudes and intentions toward pharmacist partnership on the basis of the TPB via SEM, to the best of the authors' knowledge.

\section{INTRODUCTION}

From past to today, community pharmacy market generally known as individually owned firms. ${ }^{1,2}$ However, as a result of economic pressure for pharmacists, different structures about ownership of community pharmacies are began to gain currency throughout the 20 th century. ${ }^{3}$ Community pharmacy ownership structures are generally grouped under three headings in the literature: independent, franchise or partnerships of registered pharmacists, and corporate bodies. ${ }^{1,4,5}$

Pharmacy ownership is still subject to strict governmental rules in lots of countries. Besides, regulatory changes give pharmacists an opportunity to make partnerships. Several regulations about pharmacist partnership
Submission Date: 30-08-2016; Revision Date: 17-11-2016; Accepted Date: 23-11-2016

DOI: 10.5530/ijper.51.2.27 Correspondence: Miray Arslan, Department of Pharmacy Management Ankara University Faculty of Pharmacy, 06100 Anadolu-Ankara, TURKEY. Phone: +90 (312) 2033128 E-mail: eczmirayarslan@ gmail.com

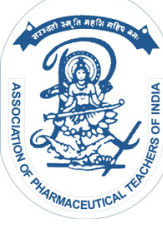

www.ijper.org 
are situated in different countries' pharmacy laws. Pharmacist partnership is allowed in many countries such as United States, Ireland, Netherlands, Norway, England, Sweden and Iceland., ${ }^{4,67}$ In some countries like Spain, Finland, Austria, Denmark, Belgium, France, Portugal and Italy pharmacist partnership is only permitted under certain conditions. Beside to this, pharmacist partnership is not allowed in countries, which have restrictive regulations about pharmacy ownership such as Germany and Turkey. ${ }^{6,8}$

The ownership types of pharmacies are important, because it plays a significant role at the services provided by pharmacists. ${ }^{3}$ The competitive structure of community pharmacy sector might prompt pharmacists to pay attention for business issues more than health issues. ${ }^{7}$ Similar to all businesses, community pharmacists must protect their profitability to continue their profession functions. In this context, partnerships are thought as a solution for taking market advantage in community pharmacy sector. Hence, community pharmacists' attitudes and intentions toward pharmacist partnership should be investigated.

In the literature there isn't any study that investigate specifically the partnership attitudes and intentions of community pharmacists. There are some studies about pharmacists intentions toward pharmacy ownership., ${ }^{5,-13}$ In some studies that took pharmacy students career preferences into consideration, it is seen that big amount of pharmacy students prefers working in community pharmacies. However, community pharmacy sector is overloaded, the ownership structure of pharmacies is an important issue ${ }^{14}$ Sweaney et al. showed that pharmacy faculty students and new graduates are interested in being an owner of independent pharmacy instead of taking part in pharmacy chains. ${ }^{12}$ Brown et al. found that pharmacists show "favorable attitude toward independent pharmacy ownership", and their "beliefs about autonomy and patient loyalty" are found as the most important factor on this issue. ${ }^{10}$ In contrast to this, Khan et al. stated that pharmacy students' have negative attitudes towards pharmacy ownership. ${ }^{13}$

Hermansen-Kobulnicky and Moss posited that students who want to be an owner of a pharmacy defined themselves more entrepreneurial. ${ }^{15}$ Perepelkin and Findlay compared corporate, franchise and independent pharmacists to investigate the effect of ownership styles, and found that independent pharmacists are the most autonomous. ${ }^{4}$ Nobrega assessed entrepreneurial aspects of pharmacists and stated that independent pharmacists are more autonomous, innovative, competitive, proactive and risk-taking than corporate pharmacists. ${ }^{16}$
Additionally, despite partnership concept is not new, the number of studies about attitudes and intentions toward business partnership are very limited, too. ${ }^{17,18}$ Studies in the literature related to business partnership mostly focused on the factors effecting partnership success. ${ }^{19-24}$ Some studies about partnership comprise the preference of partnership. ${ }^{25-27}$ And some of them about partnerships' effects on the success of the businesses. ${ }^{28,29}$ Studies about partnership in community pharmacy sector are very limited. In the literature, this issue takes part only in terms of pharmacy ownership and these studies do not address the community pharmacists' intentions towards pharmacist partnership. Knowing the significant role of attitudes and intentions in partnering behavior, a research is needed to address the community pharmacists' attitudes and intentions toward pharmacist partnership. Psychometric theories should be used to determine individuals' behavioral intention and antecedents of intention toward specific behavior. Considering the complexity of not only the partnership concept but also the community pharmacy practices, the Theory of Planned Behavior (TPB), developed by Ajzen, seems an appropriate theory for modeling partnership intention. ${ }^{30}$ There is a gap in the literature about attitudes and intentions of pharmacists towards pharmacy partnership. The main objective of the study is modeling the community pharmacists' intention towards pharmacy partnership. For this aim, attitudes, subjective norms and perceived behavior control are used as estimators of partnership intention. The originality of this study lies in being the first study that focused on attitudes and intentions toward pharmacist partnership on the basis of the TPB via structural equation model (SEM), to the best of the authors' knowledge.

The reminder of the paper is organized as follows. The following section presents the research model and hypotheses of the study. Third section presents methodology. Section four provides the results and the fifth section discusses the results in the light of the extant literature. Finally, the last section provides the conclusion.

\section{Research Model and Hypotheses}

The theoretical framework of this study is based on the Ajzen's theory of planned behavior (TPB). ${ }^{30}$ This theory is subsequent version of the Ajzen and Fishbein's theory of reasoned action (TRA). ${ }^{31}$ TPB is commonly used to identify the individuals' behavior in various fields such as management, health, marketing, education and consumer behavior. In TPB, behavioral intention should be occurred to act a specified behavior. ${ }^{32,33}$ Factors that affect the intention are "attitudes towards 
behavior", "subjective norm" and "perceived behavioral control". 32,34,35

In numerous studies, TPB constructs used to predict community pharmacists' behavioral intention towards pharmacy practices. ${ }^{36-41}$ Also, Lohana used TPB to determine pharmacy faculty students' interests in owning an independent pharmacy, and stated that attitudes and subjective norms of students effect their intention to be an owner of a pharmacy. ${ }^{42}$ Khan et al. used TPB constructs (behavioral beliefs, normative beliefs, control beliefs) to assess the pharmacy students' intentions toward being a pharmacy owner. ${ }^{13}$

In this study, Partnership Intention of Community Pharmacists (PICP) model is set by the TPB perspective (Figure 1). In PICP model, positive attitudes towards partnership, negative attitudes towards partnership, subjective norms towards partnership, and perceived behavior control towards partnership are used as estimators of the partnership intention. The research model does not contain partnership behavior. Because, the study is conducted in Turkey and pharmacist partnership has no implementation in Turkey yet.

According to TPB, attitudes toward behavior explain people's perceptions about performing a behavior in a positive or negative way. Attitude is seen as the main factor to understand human behavior. ${ }^{34}$ It can be seen that attitudes towards behavior have an important role on the behavioral intention. ${ }^{17,18,43,44}$ Weddell used attitudes to describe engaging in partnership behavior. ${ }^{45}$ Nguyen stated that attitude toward inter-firm cooperation positively effects cooperative intention. ${ }^{17}$ In addition, Noori and Nooripoor specified that individuals, who have favorable attitudes toward cooperation, are more disposed to accept cooperation system. ${ }^{46}$ In this context, to find out the relationship between positive attitudes towards behavior and partnership intention and between negative attitudes towards behavior and partnership intention, $\mathrm{H}_{1}$ "As the positive pharmacist partnership attitudes increases, partnership intention increases, as well" and $\mathrm{H}_{2}$ "As the negative pharmacist partnership attitudes increases, partnership intention decreases, as well" hypotheses were developed, respectively.

Subjective norms are the second major construct of the TPB. The most important social pressures such as parents, friends, and government etc. play a significant role on these norms. Subjective norms have two dimensions containing the perceptions, about performing a certain behavior, of important people for individuals and the effects of these people on individuals' motivation. ${ }^{47-50}$ Weddell used subjective norms to describe engaging in partnership behavior. ${ }^{45}$ Nguyen specified that subjective norms positively correlated with cooperation intention. ${ }^{17}$ Noori and Nooripoor stated that individuals feel powerful social pressures are more willing to accept cooperation system. ${ }^{46}$ Accordingly, $\mathrm{H}_{3}$ "As the subjective norms towards pharmacist partnership increases, partnership intention increases, as well" was developed for examining the relationship between subjective norms toward to pharmacist partnership and partnership intention.

Perceived behavioral control is one of the antecedents of behavioral intention in the TPB. Perceived behavioral control is used to explain a behavior is easy or difficult for individuals themselves. ${ }^{32}$ There are lots of studies that use perceived behavioral intentions to explain behavioral intention in the literature. ${ }^{51-54}$ Weddell utilized perceived behavioral intentions to take a part in partnership ${ }^{45}$ In this regard, the last hypothesis of this study, $\mathrm{H}_{4}$ "As the perceived behavioral control on pharmacist partnership increases, partnership intention increases, as well", was developed to determine the relationship between perceived behavioral control and partnership intention. The hypotheses of this study are given in Table 1.

\section{MATERIALS AND METHOD}

In this section, material and methods of the study are given.

\section{Structural equation model}

Structural equation modeling is a detailed statistical methodology for testing models that contain both causal relationship and correlations between observed variable and latent variables. SEM is used in social and behavioral sciences, education, biology, economy, marketing and medicine which is based on substantial or suggested theories that describe and explain phenomena under investigation. ${ }^{55,56} \mathrm{It}$ is used for testing several theoretical models which define the structure of constructs and their relationship with each other. ${ }^{57}$ In this context, it is seen that SEM is frequently used by social scientists to test hypotheses toward attitudes, perceptions, behavioral intentions and behavior. ${ }^{58}$

\section{Measurement}

The measurement tool used in this study was adapted from Hermansen-Kobulnicky and Moss (2004), Brown et al. (2005), Brown et al. (2007), Lohana (2010), Nobrega (2012), and Sweanay et al. (2014)., $, 10,12,15,16,42$ Attitudes and intentions are measured by 5 points Likert Scale in the measurement tool. Statements are ordered from "(1) strongly disagree" to "(5) strongly agree". There are 26 statements that contain different attitudes and intentions in the measurement tool (22 for attitude, 4 for intention). Cronbach alpha $(\alpha)$ values, which show 
the reliability of the factors in the model, are given in Table 2. Cronbach alfa $(\alpha)$ takes value between 0-1 and if it is near to 1 , the internal consistency of items within the factors increases. ${ }^{59}$

This study was performed in strict accordance with the good research practices and code of ethics of The Ankara University Ethical Committee. The measurement tool was approved by this committee with the Permit Number 130.

\section{Data collection}

The sample size of this study was calculated by the acceptable error level method under the normality assumption for the sample statistic. The sample size was calculated as 385; on 0.05 relevance level, $z=1.96$, $\mathrm{d}$ (sensitivity) $=0.05$ or $\mathrm{p}$ and q values, being 0.5 .

The measurement tool applied to 392 community pharmacists chosen randomly within the city center of Ankara by talking face to face between April 2015 and June 2015. 92 of the applied surveys were soon realized that erroneous and inconsistent and they were not included in the analyses. So, 300 of the surveys included in the analysis. $\mathrm{KMO}$ value, used to measure sampling adequacy, is calculated as 0.928 .

\section{RESULTS}

\section{Descriptive statistics}

A response rate of $77 \%$ was achieved $(n=300)$. The demographic statistics about participants are shown in Table 2. 159 of the community pharmacists participate in the study are female and 141 of them are male. Working years of community pharmacists are grouped under three groups, and it is seen that 119 of them have been working for 10 years, 83 of them between 10 to 20 years and 98 of them more than 20 years as a pharmacist. When the location of participants' pharmacies analyzed, it can be seen that 97 of them are local pharmacies and 93 of them are located near the family heath care center, 81 of them are located near the hospital, 3 of them are located in a shopping center and 26 of them are located in different places. Endorsements of the pharmacies are grouped as following: 34 of them are under $30000 \mathrm{TL}$, 131 of them are between 30000-60000 TL, 105 of them are between 60000-100000 TL and 30 of them are over $100000 \mathrm{TL}(1 \mathrm{TL} \approx 0.305 €)$.

The factor reliability was evaluated with Cronbach's alphas $(\alpha)$. As shown in Table 2 , all alpha values exceeded 0.80 , indicating that the reliability of each factor was satisfied. Also, the averages related to the items are given in Table 2. When items mean values are investigated, that can be said that they are not very high and gener- ally have closer values to each other. Examination of the items within the factors shows that the statement "Being a partner with a pharmacist leads to chain pharmacies", within the ATBN factor, has the highest average (3.603). The statement that has the highest value in the ATBP factor is "Being a partner with a pharmacist improves the quality of services offered to patients" with 3.327 mean value. "My friends support me to be a partner with a pharmacist" statement in $\mathrm{SN}$ factor and "I believe I will get along with my partner" statement in PBC factor have the highest mean values 2.457 and 2.727, respectively. Mean values of the each statement in I factor are very close and "I can make a pharmacistpharmacist partnership in the future" has the highest mean value (2.500). The results of this study show that the big amount of the participants (51\%) are not willing to pharmacy partnership in the future.

Two sample independent $t$-test is used to analyze if the gender has a significant effect on factors or not. As seen in Table 3, there is no significant difference between gender groups. One-way variance analysis (ANOVA) is used to examine if there is any significant differences between working year groups and between endorsement groups within the factors or not. Statistically significant differences are not found between groups within the factors related to partnership intention (Table 3).

Statistically significant difference is found within the ATBN factor between pharmacy location groups by the result of ANOVA (Table 3). Because of group variances are homogeneous, Tukey test is performed to find which groups are actually different from one another. As a result of the analyses, this difference is seen between pharmacies near the hospital and local pharmacies, and pharmacists of the local pharmacies have more negative attitudes toward partnership than the pharmacies near the hospital.

\section{Structural equation model results}

Several goodness-of-fit indexes are defined for SEM in the literature. These indexes describe the fitness of models by showing inconsistency between the "observed values and the values anticipated under a statistical model". ${ }^{60}$ Likelihood ratio chi-square statistics $\left(\chi^{2}\right)$, RMSEA, GFI and AGFI are the most commonly used test statistics in SEM. ${ }^{55}$

LISREL 8.80 program is used in the analysis of the data. The goodness-of-fit indexes of the model are calculated and given in Table 4. The goodness-of-fit indexes show that the research model is within the acceptable limits. ${ }^{55,57,58,61}$

Structural equation, and standardized parameter estimation values are given in Table 5. One unit increase in the 


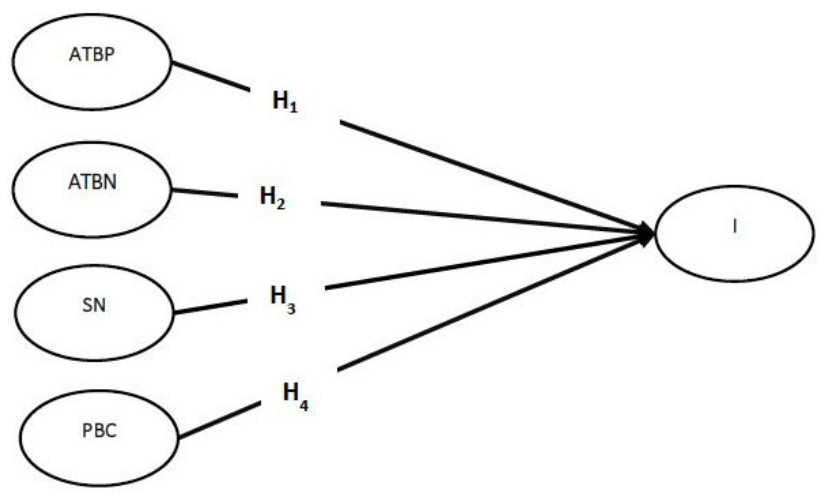

Figure 1: Research Model (Partnership Intention of Community Pharmacists Model).

"ATBP" factor causes 0.22 units increase in "I" and one unit increase in the "ATBN" factor causes 0.15 units decrease in "I" can be said by the results in Table 5 . Also, it can be seen that one unit increase in the "SN" factor and one unit increase in the "PBC" factor lead 0.37 and 0.21 units increase in the "I", respectively. Because of relations between "ATBP" $\rightarrow$ "I", "ATBN" $\rightarrow$ "I", "SN" $\rightarrow$ "I", and "PBC" $\rightarrow$ "I" are found statistically significant, all of the research hypotheses are confirmed. $\mathrm{R}^{2}$ value, related to the "Partnership Intention of Community Pharmacists (PICP) model", is found as 0.66. This value shows that the factors explain $66 \%$ of the variation within "I".

Furthermore, in the developed structural equation model, it is seen that positive attitudes towards behavior, subjective norms, and perceived behavioral control have booster effect on the partnership intention of community pharmacists. Conversely, it is seen that negative attitudes towards behavior play a detractive role for the partnership intention of the community pharmacists. In addition, correlation matrix, related to the factors is given in Table 6.

A structural equation model for the partnership intention of the community pharmacists can be seen in Figure 2 . As mentioned above, positive attitudes towards behavior, negative attitudes towards behavior, subjective norms and perceived behavioral control explain $66 \%$ of the variation in the community pharmacists' partnership intention.

\section{DISCUSSION}

\section{Discussion of descriptive statistics}

In this section, demographical results of this study is discussed. Brown et al. pointed out that career stage of community pharmacists affects the attitudes of the community pharmacists toward independent pharmacy

\section{Table 1: Research Hypotheses}

Hypotheses

$\mathrm{H}_{1}$ As the positive pharmacist partnership attitudes increases, partnership intention increases, as well.

$\mathrm{H}_{2}$ As the negative pharmacist partnership attitudes increases, partnership intention decreases, as well.

$\mathrm{H}_{3}$ As the subjective norms towards pharmacist partnership increases, partnership intention increases, as well.

$\mathrm{H}_{4}$ As the perceived behavioral control on pharmacist partnership increases, partnership intention increases, as well.

\begin{tabular}{|c|c|}
\hline Factors / Cronbach Alpha ( $\alpha$ ) / Items & Means \\
\hline $\begin{array}{c}\text { Positive Attitudes Towards Behavior (ATBP) / } \\
\text { Cronbach Alpha }(\alpha)=0.85 \\
\text { atbp1. Being a partner with a pharmacist reduces the } \\
\text { workload } \\
\text { atbp2. Being a partner with a pharmacist improves the } \\
\text { quality of services offered to patients } \\
\text { atbp3. Being a partner with a pharmacist increases } \\
\text { the financial power }\end{array}$ & \begin{tabular}{|l|}
3.017 \\
3.327 \\
3.089
\end{tabular} \\
\hline $\begin{array}{c}\text { Negative Attitudes Towards Behavior (ATBN) / } \\
\text { Cronbach Alpha }(\alpha)=0.81 \\
\text { atbn2. Being a partner with a pharmacist complicates } \\
\text { the decision-making process } \\
\text { atbn4. Being a partner with a pharmacist leads to } \\
\text { chain pharmacies } \\
\text { atbn5. Being a partner with a pharmacist affects } \\
\text { pharmacy profession negatively }\end{array}$ & $\begin{array}{l}3.527 \\
3.603 \\
3.287\end{array}$ \\
\hline $\begin{array}{l}\text { Subjective Norms (SN) / Cronbach Alpha }(\alpha)=0.85 \\
\text { sn2. My friends support me to be a partner with a } \\
\text { pharmacist } \\
\text { sn3. My colleagues support me to be a partner with a } \\
\text { pharmacist } \\
\text { sn4. My family supports me to be a partner with a } \\
\text { pharmacist }\end{array}$ & \begin{tabular}{|l}
2.457 \\
2.423 \\
2.387
\end{tabular} \\
\hline $\begin{array}{l}\text { Perceived Behavioral Control (PBC) / Cronbach Alpha } \\
\qquad(\alpha)=0.95 \\
\text { pbc2. I believe that the partnership is easy for me } \\
\text { pbc3. I believe I have the appropriate properties for } \\
\text { partnership } \\
\text { pbc4. I believe I can adapt easily to partnership } \\
\text { pbc5. I believe I will get along with my partner } \\
\text { pbc6. I believe that I can beat the challenges I face in } \\
\text { partnership } \\
\text { pbc7. I believe I can easily fulfill the partnership } \\
\text { conditions }\end{array}$ & $\begin{array}{l}2.427 \\
2.663 \\
\\
2.567 \\
2.727 \\
2.683 \\
2.717\end{array}$ \\
\hline $\begin{array}{l}\text { Partnership Intention (I) / Cronbach Alpha }(\alpha)= \\
0.94 \\
\text { i1. I can make a pharmacist-pharmacist partnership in } \\
\text { the future } \\
\text { i2. I can be a partner to a pharmacy in the future } \\
\text { i3. I can take a partner to my pharmacy in the future }\end{array}$ & \begin{tabular}{|l|}
2.500 \\
\\
2.453 \\
2.473 \\
\end{tabular} \\
\hline
\end{tabular}

ownership. ${ }^{9}$ Contrarily to literature, in this study, statistically significant difference is not found between the working years groups of community pharmacists in any of the factors (ATBP, ATBN, SN, and PBC). Similar to findings of this study, Dobson and Perepelkin did 


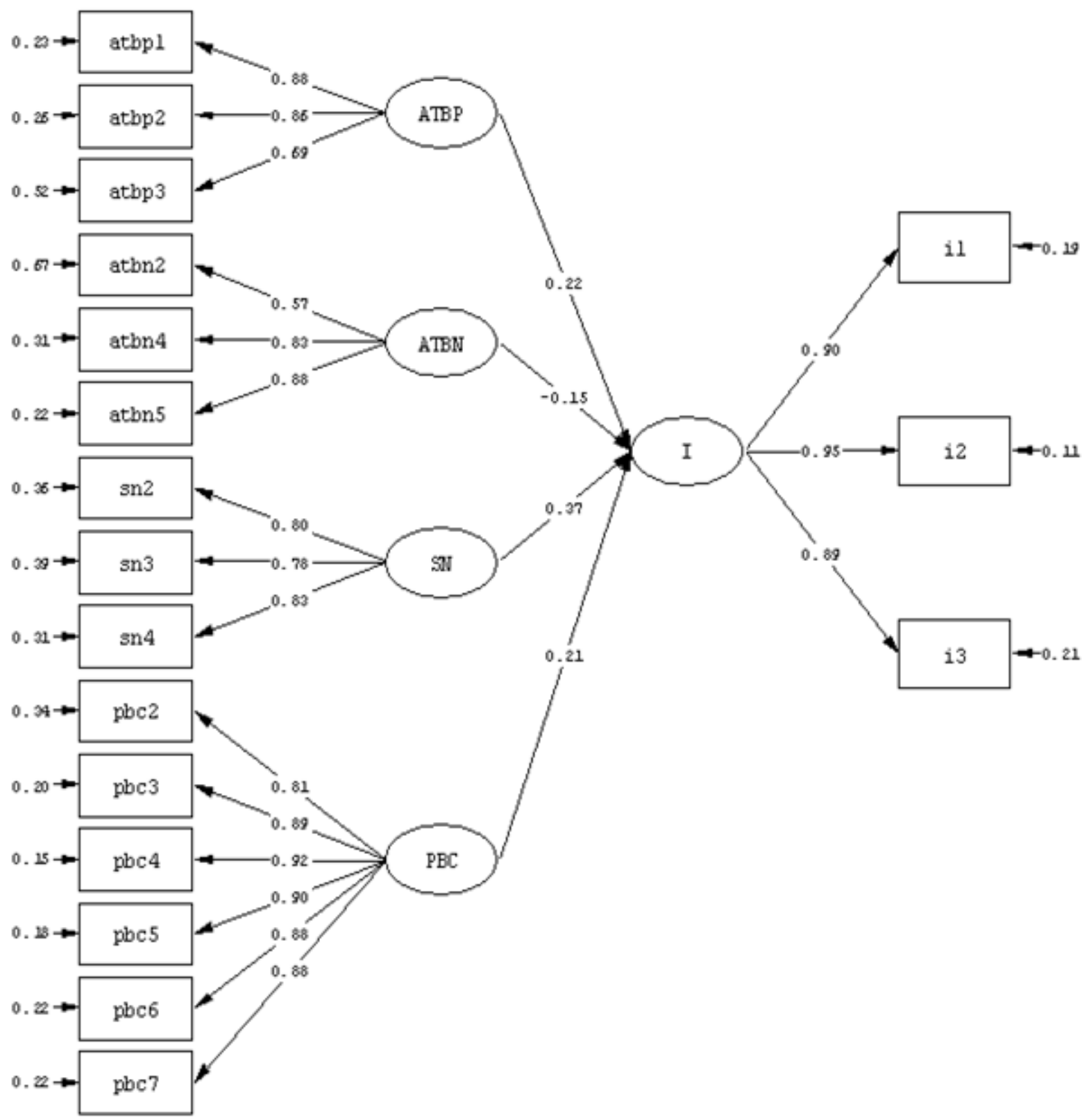

Figure 2: Partnership Intention of Community Pharmacists

(PICP) Model LISREL 8.80 Output.

\begin{tabular}{|c|c|c|c|c|c|c|c|c|}
\hline \multicolumn{9}{|c|}{ Table 3: Two sample independent t-test and ANOVA Results } \\
\hline & \multicolumn{2}{|c|}{ Gender } & \multicolumn{2}{c|}{ Working Year } & \multicolumn{2}{c|}{ Endorsement } & \multicolumn{2}{c|}{ Location } \\
\hline Factors & T & sig. & F & sig. & F & sig. & F & sig. \\
\hline ATBP & -0.373 & 0.710 & 0.635 & 0.531 & 0,561 & 0.641 & 1.730 & 0.143 \\
\hline ATBN & 1.031 & 0.304 & 0.438 & 0.645 & 2.356 & 0.072 & $3.590^{*}$ & 0.007 \\
\hline SN & 0.534 & 0.594 & 0.058 & 0.944 & 1.188 & 0.315 & 1.255 & 0.288 \\
\hline PBC & -0.790 & 0.430 & 0.531 & 0.589 & 1.077 & 0.359 & 2.383 & 0.052 \\
\hline I & -0.306 & 0.760 & 0.063 & 0.939 & 1.826 & 0.142 & 2.220 & 0.067 \\
\hline
\end{tabular}

* The mean difference is significant at the 0.05 level 


\begin{tabular}{|c|c|c|c|}
\hline Fit Measures & Good Fit & Acceptable Fit & Developed Model \\
\hline$x^{2} /$ d.f. & $0 \leq x^{2} /$ d.f. $<2$ & $2 \leq x^{2} /$ d.f. $\leq 3$ & 2,726 \\
\hline RMSEA & $0<$ RMSEA $<0.05$ & $0.05 \leq \mathrm{RMSEA} \leq 0.10$ & 0.076 \\
\hline RMR & $0 \leq R M R \leq 0.05$ & $0.05<\mathrm{RMR} \leq 0.10$ & 0.062 \\
\hline $\mathrm{NFI}$ & $0.95 \leq \mathrm{NFI} \leq 1$ & $0.90 \leq \mathrm{NFI} \leq 0.95$ & 0.97 \\
\hline NNFI & $0.97 \leq \mathrm{NNFI} \leq 1$ & $0.95 \leq \mathrm{NNFI} \leq 0.97$ & 0.98 \\
\hline $\mathrm{CFI}$ & $0.97 \leq \mathrm{CFI} \leq 1$ & $0.95 \leq \mathrm{CFI} \leq 0.97$ & 0.98 \\
\hline GFI & $0.95 \leq \mathrm{GFI} \leq 1$ & $0.90 \leq \mathrm{GFI} \leq 0.95$ & 0.89 \\
\hline AGFI & $0.90 \leq A G F I \leq 1$ & $0.85 \leq A G F I \leq 0.90$ & 0.85 \\
\hline
\end{tabular}

\begin{tabular}{|c|c|c|c|c|}
\hline Hypothesis & Paths & $\begin{array}{c}\text { Std. } \\
\text { Parameters } \\
\text { estimation } \\
\text { values }\end{array}$ & t-value & Result \\
\hline $\mathrm{H}_{1}$ & $\mathrm{ATBP} \rightarrow \mathrm{I}$ & 0.22 & 3.28 & Confirmed \\
\hline $\mathrm{H}_{2}$ & $\mathrm{ATBN} \rightarrow \mathrm{I}$ & -0.15 & -2.83 & Confirmed \\
\hline $\mathrm{H}_{3}$ & $\mathrm{SN} \rightarrow \mathrm{I}$ & 0.37 & 4.91 & Confirmed \\
\hline $\mathrm{H}_{4}$ & $\mathrm{PBC} \rightarrow \mathrm{I}$ & 0.21 & 3.30 & Confirmed \\
\hline \multicolumn{3}{|c|}{$\begin{array}{c}\text { Structural Equation } \\
\mathrm{I}=0.22^{*} \mathrm{ATBP}-0.15^{*} \mathrm{ATBN}+0.37^{\star} \mathrm{SN}+ \\
0.21^{*} \mathrm{PBC}\end{array}$} & $R^{2}=0.66$ & \\
\hline
\end{tabular}

\begin{tabular}{|c|c|c|c|c|c|}
\multicolumn{6}{|c|}{ Table 6: Correlation matrix related to the factors } \\
\hline & I & ATBP & ATBN & SN & PBC \\
\hline I & 1.00 & & & & \\
\hline ATBP & 0.69 & 1.00 & & & \\
\hline ATBN & -0.58 & -0.48 & 1.00 & & \\
\hline SN & 0.75 & 0.68 & -0.56 & 1.00 & \\
\hline PBC & 0.69 & 0.67 & -0.54 & 0.68 & 1.00 \\
\hline
\end{tabular}

not find statistically significant difference between age groups on the pharmacy ownership structure. ${ }^{11}$

Cliff observed that small businesses are more attractive for female entrepreneurs in terms of ensuring the balance between social and business life. ${ }^{62}$ In the view of pharmacy profession, the smallest business structure can be seen as owning an independent community pharmacy. So it is thought that there might be a difference between genders in their partnership intention because of joining a partnership makes business structure bigger. But, inversely to literature, no statistically significant difference between genders is found within the factors related to partnership intention.

\section{Discussion of the structural equation model results}

In this section, discussion about structural equation model is given. All of the research hypotheses are confirmed and the PICP model showed that partnership intention (I) affects from ATBP, ATBN, SN and PBC.

It is found that ATBP and ATBN can be used as estimators of the partnership intention. It is observed that pharmacy students' and pharmacists' attitudes are commonly used by researchers in several studies about pharmacy practice and education. ${ }^{63-67}$ In addition, findings of this study are parallel to the literature about partnership and other types of business collaborations, too. ${ }^{17,18,45,46}$ In this regard, both of $\mathrm{H}_{1}$ and $\mathrm{H}_{2}$ hypotheses are supported by the literature. Furthermore, when means of ATBP and ATBN factors' items are taken into account, it can be seen that they are well-matched with the related literature. Similar to Lohana, being an owner of a pharmacy was seen as a situation which is riskier, increases workload and requires more time and responsibility. ${ }^{42}$ Beside this, positive attitudes of pharmacists toward partnership behavior, which contain financial power, service quality, and workload, effect the partnership intention in a positive way in the present research. It is noticed that entrepreneur pharmacists can focus on their profession more than corporate 
pharmacists in the literature., ${ }^{4,68}$ Additionally, Lohana stated that independent community pharmacy ownership has lots of advantages such as independently decision making. ${ }^{42}$ Dobson and Perepelkin indicated that pharmacists work in independent pharmacies have the most "decision-making ability" and pharmacists work in franchises and corporations follow it respectively. ${ }^{11}$ Such as mentioned above, the participants of the present study thought that being a partner with a pharmacist makes decision-making process complex and the result of this, it affects pharmacy profession negatively.

In the proposed PICP model, one unit increase in SN positively affects partnership intention higher than other factors (ATBP, ATBN, and PBC). Finding the subjective norm construct as the strongest predictor is parallel to literature addressing community pharmacists' behavioral intention. ${ }^{36-38,41}$ The last component which also effects partnership intention positively is $\mathrm{PBC}$ in PICP model. As remarked in previous studies related with partnership and other types of business relationships ${ }^{17,18,45,46} \mathrm{SN}$ and PBC are used as estimators of partnership intention in the present study. In this context, $\mathrm{H}_{3}$ and $\mathrm{H}_{4}$ hypotheses are supported by the literature, too.

Although this study advances many new insights, it is not without its limitations. One limitation is that there is a wide variety of examples of partnership in the literature, so determining the most suitable one for pharmacy practice was hard for authors. In this study only partnerships between community pharmacists were taken into account. Due to the time and resource restrictions, the study was conducted employing a quantitative approach. Including qualitative design for investigating in-depth analysis of personal beliefs, attitudes and feelings would provide insight about the partnership intention. The study is done from the perspective of the community pharmacists, who are the owner of a pharmacy. So, further research can be conducted from the perspective of the pharmacy students or pharmacists who are not an owner of a pharmacy.

\section{CONCLUSION}

The present work contributes to the community pharmacy literature by developing a structural model for partnership intention that contains attitudes, subjective norms and perceived behavioral control. This study opens doors to a variety of perspectives for future research. The extension of the proposed PICP model can be used in modeling the pharmacists' behaviors toward pharmacist partnership. Hence, further research is planned as extend the PICP model by adding partner- ship behavior for different countries which have pharmacist partnership practices. Also, there is not found any study about business owners' intentions towards to business partnership, to the best of authors' knowledge. Therefore, the authors want to notice that proposed PICP model can be adapted to businesses in other fields. The authors also want to state that they are willing to study with researchers keen on this topic.

\section{ACKNOWLEDGMENT}

The authors want to thank community pharmacists who participated in this study.

\section{CONFLICT OF INTEREST}

There is no conflict of interest.

\section{ABBREVIATIONS USED}

AGFI: Adjusted Goodness of Fit Index; ATBP: Positive Attitudes Towards Partnership Behavior; ATBN: Negative Attitudes Towards Partnership Behavior; CFI: Comparative Fit Index; GFI: Goodness of Fit Index; KMO: Kaiser-Meyer-Olkin; NFI: Normed Fit Index; NNFI: Non-Normed Fit Index; I: Partnership Intention; SN: Subjective Norms; PBC: Perceived Behavioral Control; PICP: Partnership Intention of Community Pharmacists; RMSEA: Root Mean Square Error of Approximation; SEM: Structural Equation Model.

\section{REFERENCES}

1. Ottewill R, Magirr P. Changes in the Ownership of Community Pharmacies: Policy Implications. Public Money Manage. 1999;19(2):39-44. https://doi. org/10.1111/1467-9302.00164.

2. Anell A. Deregulating the pharmacy market: the case of Iceland and Norway. Health Policy. 2005;75(1):9-17. https://doi.org/10.1016/j.healthpol. 2005.01.020 PMid:16298225.

3. Bush J, Langley CA, Wilson KA. The corporatization of community pharmacy: Implications for service provision, the public health function, and pharmacy's claims to professional status in the United Kingdom. RSAP. 2009;5(4):305-18. https://doi.org/10.1016/j.sapharm.2009.01.003.

4. Perepelkin J, Findlay IM. Autonomy and orientation of entrepreneurial community pharmacists and corporate pharmacy managers: A comparative study. University of Saskatchewan, Edwards School of Business; 2009.

5. Perepelkin J, Dobson RT. Influence of ownership type on role orientation, role affinity, and role conflict among community pharmacy managers and owners in Canada. RSAP. 2010;6(4):280-92. https://doi.org/10.1016/j. sapharm.2009.11.001.

6. Vogler S, Arts D, Sandberger K. Impact of pharmacy deregulation and regulation in European countries. Vienna: Gesundheit Österreich Forschungs und Planungs $\mathrm{GmbH} ; 2012$.

7. Vogler S, Habimana K, Arts D. Does deregulation in community pharmacy impact accessibility of medicines, quality of pharmacy services and costs? Evidence from nine European countries. Health Policy. 2014;117(3):311-27. https://doi.org/10.1016/j.healthpol.2014.06.001 PMid:24962537.

8. Turkish Law. Eczacılar ve Eczaneler Hakkında Kanun. Law No. 6197. 18 December 1953. Issue of Turkish Official Gazette: 8591. [cited 1 June 2016]. Available from: http://www.mevzuat.gov.tr/MevzuatMetin/1.3.6197.pdf. 
9. Brown C, Cantu R, Corbell Z, Roberts K. Examining the Attitudes and Interests of Pharmacists Regarding Pharmacy Ownership. University of Texas, Pharmacy Administration Division, College of Pharmacy, Austin, TX. 2005;78712-1074.

10. Brown CM, Cantu R, Corbell Z, Roberts K. Attitudes and interests of pharmacists regarding independent pharmacy ownership. J Am Pharm Assoc. 2007;47(2):174-80. https://doi.org/10.1331/EN88-W778-261P-3134 https://doi.org/10.1331/D525-0970-21X5-8UU7 PMid:17510004.

11. Dobson RT, Perepelkin J. Pharmacy ownership in Canada: Implications for the authority and autonomy of community pharmacy managers. RSAP. 2011;7(4):347-58. https://doi.org/10.1016/j.sapharm.2010.10.005.

12. Sweanay AM, Casper KA, Hoyt CD, Wehr AM. Student pharmacists' and recent graduates' perception of and interest in independent pharmacy ownership. Inov Pharm. 2014;5(4):5. Article 182.

13. Khan MU, Ahmad A, Fayyaz M, Ashaf N, Bhagavathula A. Exploring the intentions of pharmacy students towards pharmacy ownership by using theory of planned behavior. BMC Res Notes. 2016;9:183-9. https://doi. org/10.1186/s13104-016-1996-4 PMid:27005815 PMCid:PMC4804628.

14. Han AR, Gil M, Bae SJ. Factors associated with the Career Preference of 6-Year Doctor of Pharmacy (Pharm.D) Students in Korea: a National Survey. Indian J Pharm Educ. 2016;50(3):321-9. https://doi.org/10.5530/ijper.50.3.2.

15. Hermansen-Kobulnicky CJ, Moss CL. Pharmacy Student Entrepreneurial Orientation: A Measure to Identify Potential Pharmacist Entrepreneurs. Am J Pharm Educ. 2004;68(5):113. https://doi.org/10.5688/aj6805113.

16. Nobrega C. An assessment of the entrepreneurial orientation of pharmacists in Gauteng. North-West University, Potchefstroom Campus. 2012.

17. Nguyen NP. Applying "Theory of Reasoned Action" To Explain Inter-Firm Cooperation: Empirical Evidence from Vietnamese Enterprises. IJMIS. 2011;15(3):61-81. https://doi.org/10.19030/ijmis.v15i3.4643.

18. Nguyen NP. Inter-Firm Cooperation under the View of Theory of Planned Behavior: The Case of Vietnam. International Conference on Applied Economics-ICOAE. 2011;425-34. PMid:21380922.

19. Harrigan KR. Strategic alliances and partner asymmetries. Manag Int Rev. 1988;28:53-72.

20. Mohr J, Spekman R. Characteristics of Partnership Success: Partnership Attributes, Communication Behaviour and Conflict Resolution Techniques. SMJ. 1994;15(2):135-52. https://doi.org/10.1002/smj.4250150205.

21. Casey M. Partnership-success factors of inter-organizational relationships. J Nurs Manag. 2008;16:72-83. PMid:18211338.

22. Cui AS, Calantonw RJ, Griffith DA. Strategic Change and Termination of Interfirm Partnerships. SMJ. 2011;32(4):402-23. https://doi.org/10.1002/ smj.881.

23. Glasbergen P. Understanding Partnerships for Sustainable Development Analytically: the Ladder of Partnership Activity as a Methodological Tool. Env Pol Gov. 2011;21(1):1-13. https://doi.org/10.1002/eet.545.

24. Espinosa MB, Soriano DR. Cooperative learning in creating and managing joint ventures. J Bus Res. 2014;67(4):648-55. https://doi.org/10.1016/j. jbusres.2012.12.017.

25. Rese M. Successful and sustainable business partnerships: How to select the right partners. Ind Market Manag. 2006;35(1):72-82. https://doi. org/10.1016/j.indmarman.2005.08.009.

26. Freeman S, Edwards R, Schroder RB. How smaller born-global firms use networks and alliances to overcome constraints to rapid internationalization. J Int Marketing. 2006;14(3):33-63. https://doi.org/10.1509/jimk.14.3.33.

27. Frimpong AO. Impact of Entrepreneurship Education on Partnership Venture Intentions. Journal of Behavioural Economics Finance Entrepreneurship Accounting and Transport. 2014;2(3):63-9.

28. Kolk A, Tulder R, Kostwinder E. Business and partnerships for development. Eur Manage J. 2008;26(4):262-73. https://doi.org/10.1016/j.emj.2008.01.007.

29. Dan W, Xiona Y. On Business Collaboration Patterns: A Comparative Study between Europe and China. International Conference on Management Science \& Engineering (ICMSE 2009). Russia. 2009;344-9.

30. Ajzen I. From intentions to actions: A theory of planned behavior. In Kuhl J. and Beckman J. editors. Action control: From cognition to behavior. Heidelberg: Springer; 1985. p. 11-39. https://doi.org/10.1007/978-3-64269746-3_2.

31. Ajzen I, Fishbein M. Understanding attitudes and predicting social behavior. Englewood Cliffs, NJ: Prentice-Hall. 1980.
32. Ajzen I. The theory of planned behavior. Organ Behav Hum Decis Process 1991;50(2):179-211. https://doi.org/10.1016/0749-5978(91)90020-T.

33. Xiao JJ, Wu J. Completing Debt Management Plans in Credit Counseling: An Application of the Theory of Planned Behavior. JFCP. 2008;19(2):29-45.

34. Ajzen I, Fishbein M. Attitudes and the attitude behavior relation: Reasoned and automatic process. Eur Rev Soc Psychol. 2000;11:1-33. https://doi. org/10.1080/14792779943000116.

35. Ajzen, I. Attitudes, personality and behavior. New York: Open University Press; 2005.

36. Herbert KE, Urnie JM, Newland BA, Farris KB. Prediction of pharmacist intention to provide Medicare medication therapy management services using the theory of planned behavior. RSAP. 2006;2(3):299-314. https://doi. org/10.1016/j.sapharm.2006.02.008.

37. Gavaza P, Brown CM, Lawson KA, Rascati KL, Wilson JP, Steinhardt M. Examination of pharmacists' intention to report serious adverse drug events (ADEs) to the FDA using the theory of planned behavior. RSAP. 2011;7(4):369-82. https://doi.org/10.1016/j.sapharm.2010.09.001.

38. Fleeming ML, Barner JC, Brown CM, Shepherd MD, Strassels S, Novak S. Using the theory of planned behavior to examine pharmacists' intention to utilize a prescription drug monitoring program database. RSAP. 2014;10(2):285-96. https://doi.org/10.1016/j.sapharm.2013.05.009.

39. Gavaza P, Fleming M, Barner JC. Examination of psychosocial predictors of Virginia pharmacists' intention to utilize a prescription drug monitoring program using the theory of planned behavior. RSAP. 2014;10(2):448-58. https://doi.org/10.1016/j.sapharm.2013.06.011.

40. Amin MEK, Chewning B. Predicting pharmacists' adjustment of medication regimens in Ramadan using the theory of planned behavior. RSAP. 2015;11:1-15. https://doi.org/10.1016/j.sapharm.2014.04.004.

41. Puspitasari HP, Costa DSJ, Aslani P, Krass I. An explanatory model of community pharmacists' support in the secondary prevention of cardiovascular disease. RSAP. 2016;12:104-18. https://doi.org/10.1016/j. sapharm.2015.04.008.

42. Lohana B. Pharmacy Ownership Interest of Pharmacy Students. Theses and Dissertations. Paper 900; 2010.

43. Greaves M, Zibarras LD, Stride C. Using the theory of planned behavior to explore environmental behavioral intentions in the workplace. J Environ Psychol. 2013;34:109-20. https://doi.org/10.1016/j.jenvp.2013.02.003.

44. Kautonen T, Gelderen M, Tornikoski ET. Predicting entrepreneurial behaviour: a test of the theory of planned behavior. Appl Econ. 2013;45(6):697-707. https://doi.org/10.1080/00036846.2011.610750.

45. Weddell M. Towards a Model of Intention To Perform Partnership Behaviors: An Application of The Theory of Planned Behavior. All Dissertations. 2007; Paper 106.

46. Noori M, Nooripoor M. Applicability of the Theory of Planned Behavior (TPB) to Predict Acceptance of Cooperative System: The Case of Boyer-Ahmad County. Journal of Applied Sociology. 2013;51:43-8.

47. Kolvereid L. Prediction of employment status choice intentions. Entrep Theory Pract. 1996;21(1):47-57.

48. Krueger NF, Reilly MD, Carsrud AL. Competing Models of Entrepreneurial Intentions. J Bus Venturing. 2000;15(5):411-32. https://doi.org/10.1016/ S0883-9026(98)00033-0.

49. George JF. The theory of planned behavior and Internet purchasing. Internet Research. 2004;14(3):198-212. https://doi.org/10.1108/10662240410542634.

50. Kautonen T, Gelderen M, Tornikoski ET. Robustness of the Theory of Planned Behavior in Predicting Entrepreneurial Intentions and Actions. Entrep Theory Pract. 2015;39(3):655-74. https://doi.org/10.1111/etap.12056.

51. Taylor S, Todd P. Decomposition and crossover effects in the theory of planned behavior: A study of consumer adoption intentions. Intern $\mathrm{J}$ of Research in Marketing. 1995;12(2):137-55. https://doi.org/10.1016/01678116(94)00019-K.

52. Hrubes D, Ajzen I, Daigle J. Predicting Hunting Intentions and Behavior: An Application of the Theory of Planned Behavior. Leisure Sci. 2001;23(3):165-78. https://doi.org/10.1080/014904001316896855.

53. Gelderen M, Brand M, Praag M, Bodewes W, Poutsma E, Gils A. Explaining entrepreneurial intentions by means of the theory of planned behaviour. Career Dev Int. 2008;13(6):538-59. https://doi.org/10.1108/13620430810901688. 
54. Han H, Hsu L, Sheu C. Application of the Theory of Planned Behavior to green hotel choice: Testing the effect of environmental friendly activities. Tourism Manage. 2010;31(3):325-34. https://doi.org/10.1016/j.tourman.2009.03.013.

55. Raykov T, Marcoulides GA. A first course in structural equation modeling. London: Lawrence Erlbaum Associates. 2006.

56. Dursun Y, Kocagöz E. Yapısal Eşitlik Modellemesi ve Regresyon: Karşılaştırmalı Bir Analiz. ERÜ İktisadi ve İdari Bilimler Fakültesi Dergisi. 2010;35:1-17

57. Schumacker RE, Lomax RG. A beginner's guide to structural equation modeling. 3rd Edition. Taylor and Francis Group: New York. 2010.

58. Arslan T, Yılmaz V, Aksoy, HK. Structural Equation Model for Environmentally Conscious Purchasing Behavior. Int J Environ Res. 2012;6(1):323-34.

59. Gliem JA, Gliem RR. Calculating, Interpreting, and Reporting Cronbach's Alpha Reliability Coefficient for Likert-Type Scales. 2003 Midwest Research to Practice Conference in Adult, Continuing, and Community Education October 8-10, Columbus. 2003;82-8.

60. Maydeu-Olivares A, Garcı'a-Forero C. Goodness-of-Fit Testing. International Encyclopedia of Education. 2010;7:190-6. https://doi.org/10.1016/B978-008-044894-7.01333-6.

61. Hooper D, Coughlan J, Mullen M. Structural Equation Modelling: Guidelines for Determining Model Fit. EJBMR. 2008;6:53-60.

\section{PICTORIAL ABSTRACT}

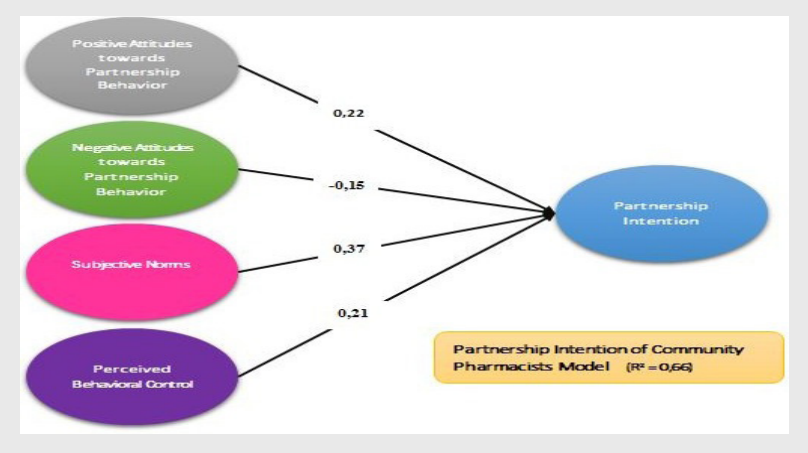

\section{About Authors}

Miray Arslan: PhD candidate and research assistant at Ankara University, Faculty of Pharmacy, Department of Pharmacy Management. Also, graduated from Anadolu University Faculty of Business Administration and undergraduate student at Eskişehir Osmangazi University Industrial Engineering Faculty. Interested in Pharmacy Management, Social Pharmacy, History of Pharmacy, ethics, Pharmacy Education, Pharmacoeconomics, Pharmaceutical Logistics.
62. Cliff JE. Does one size fit all? Exploring the relationship between attitudes towards growth, gender, and business size. J Bus Venturing. 1998;13(6):523-42. https://doi.org/10.1016/S0883-9026(97)00071-2.

63. Sancez AMM, Sol AB. Assessment of Attitudes of Cuban University Pharmacy Students Toward Pharmaceutical Care. Indian J Pharm Educ. 2016;50:504-11. https://doi.org/10.5530/ijper.50.4.1.

64. Ahmad A, Khan MU, Kumar BD, Kumar GS, Rodriguez SP, Patel I. Beliefs, attitudes and self-use of Ayurveda, Yoga and Naturopathy, Unani, Siddha, and Homeopathy medicines among senior pharmacy students: An exploratory insight from Andhra Pradesh, India. Phcog Res. 2015;7(4):302-8. https://doi. org/10.4103/0974-8490.158438 PMid:26692742 PMCid:PMC4660507.

65. Jocic DD, Krajnovic DM. State Anxiety, Stress and Burnout Syndrome Among Community Pharmacists: Relation With Pharmacists' Attitudes and Beliefs. Indian J Pharm Educ. 2014;48(2):9-15. https://doi.org/10.5530/ijper.48.2.3.

66. Wang J, Hu X, Chen Y, Xu S. Chinese Pharmacy Undergraduate Attitudes toward Game-Based Learning in Pharmaceutical Education. Indian J Pharm Educ. 2013;47(3):6-13. https://doi.org/10.5530/ijper.47.3.2.

67. Aditya S Rattan A. Minimizing pharmaceutical waste: The role of the pharmacist. J Young Pharm. 2014;6(3):14-9. https://doi.org/10.5530/ jyp.2014.3.3.

68. Muzzin L, Brown G, Hornosty R. Consequences of Feminization of a Profession: The Case of Canadian Pharmacy. Women Health. 1994; 21(2-3):39-56. https://doi.org/10.1300/J013v21n02_03 PMid:8073786.

\section{SUMMARY}

- A structural equation model based on the "Theory of Planed Behavior" is developed for the partnership intention of the community pharmacists.

- The proposed model showed that partnership intention (I) affects from positive attitudes towards behavior (ATBP), negative attitudes towards behavior (ATBN), subjective norms (SN), and perceived behavioral control (PBC).

- Structural equation shows that one unit increase in the "ATBP" factor causes 0.22 units increase in "I", one unit increase in the "ATBN" factor causes 0.15 units decrease in "I", one unit increase in the "SN" factor and one unit increase in the "PBC" factor lead 0.37 and 0.21 units increase in the "I", respectively.

- R2 value, related to the "Partnership Intention of Community Pharmacists (PICP) model", is found as 0.66 . This value shows that the factors explain $66 \%$ of the variation within "I".

Nilay Tarhan: PhD candidate and research assistant at Ankara University, Faculty of Pharmacy, Department of Pharmacy Management. And also PhD candidate at Ankara University, Faculty of Pharmacy, Department of Pharmacology. In addition, graduated from Anadolu University Faculty of Business Administration. Interested in Pharmacy Management, Social Pharmacy, History of Pharmacy, Ethics, Pharmacy Education, Pharmacoeconomics, Pharmacovigilance, Diabetes Mellitus, Cardiovascular System.

Sevgi Șar: Prof. Dr. at Ankara University, Faculty of Pharmacy, Department of Pharmacy Management. Interested in Pharmacy Management, Social Pharmacy, History of Pharmacy, Ethics, Pharmacy Education.

Cite this article: Arslan M, Tarhan N, Sar S. Examination of the Community Pharmacists' Intention to Pharmacist Partnership Using the Theory of Planned Behavior: A Structural Equation Model. Indian J of Pharmaceutical Education and Research. 2017;51(2):216-25. 